\title{
Marketing Analysis of Striped Catfish Pond Cultivation in Basarang Village Basarang Sub-district Kapuas Regency Central Kalimantan
}

\author{
Deni Subekti ${ }^{1}$ Emmy Sri Mahreda ${ }^{2} \quad$ Emmy Lilimantik $^{2 *}$ \\ 1.Magister student of Fishery Program, University of Lambung Mangkurat, South Kalimantan, Indonesia \\ 2.Faculty of Fishery and Marine, University of Lambung Mangkurat, South Kalimantan, Indonesia
}

\begin{abstract}
This present study aims to determine the marketing system of catfish cultivated in Basarang Village, Kapuas Regency, Central Kalimantan. The method used in this study are : (1) marketing channels with the snowball sampling method (2) Farmer's share (3) marketing margin and (4) The analysis of structure, conduct and performance using the analysis of (a) market integration and (b) price transmission elasticity. The analysis shows that (1) striped catfish marketing channels consist of 2 marketing systems, (2) Farmer's share in the first channel is $70.90 \%$ and in the second channel is $86.57 \%$, (3) Total of the marketing margin on the pattern 1 is $41.03 \%$ and the pattern 2 is $15.51 \%$ and (4) the analysis of structure, conduct and performance shows that (a) the results of market integration analysis obtained a regression coefficient $(\beta)$ of 0.083 which indicates that the market structure is oligopsony and (b) the results of the analysis of price transmission elasticity $(\eta)$ on channel 1 amounted to pattern 1 of 0.059 and pattern 2 to amount to 0.072 which means that price changes in elastic.
\end{abstract}

Keywords: Striped Catfish, Marketing Channels, Margin, Farmer's Share, Market Integration and Price Transmission Elasticity

DOI: $10.7176 / \mathrm{JMCR} / 65-03$

Publication date: February $29^{\text {th }} 2020$

\section{Introduction}

Kapuas Regency is one of the districts in Central Kalimantan that has a very promising potential for fishery resources. This can be seen as the Kapuas Regency appointed as one of the Regencies in Indonesia that become a model for the cultivation of the minapolitan area in 2011. Decree of the Director General of Aquaculture Fisheries Number 70 / DJ-PB / 2010 concerning about the Establishment of a Pilot Minapolitan Area Cultivation issued on November 1, 2010 aims to encourage the acceleration of regional development with fishery activities as the main occupation in improving the standard of living, income and welfare of the community as well as encouraging village connection with the city. Aquaculture production in Kapuas Regency in 2017 and 2018 is presented in Table 1.

Table 1. Aquaculture production in Kapuas Regency in 2017 and 2018.

\begin{tabular}{|c|l|r|r|}
\hline \multirow{2}{*}{ No } & \multicolumn{2}{|c|}{ Type of Fish } & \multicolumn{2}{|c|}{ Production (ton) } \\
\cline { 3 - 4 } & Striped Catfish & 11.019 .36 & \multicolumn{1}{c|}{2018} \\
\hline 1 & Climbing perch & 91.86 & 10.348 .33 \\
\hline 2 & Tilapia & 250.35 & 63.50 \\
\hline 3 & 77.22 & 314.67 \\
\hline 4 & Catfish & & 105.17 \\
\hline
\end{tabular}

Source : Official Report of the Fisheries and Maritime Division in Kapuas Regency in 2019.

Table 1 shows that the most aquaculture production is striped catfish with a production of $11,019,36$ tons in 2017, but in 2018 it decreased by $6.9 \%$ to 10,348.33 tons. Despite the decreased that happened, striped catfish is still the biggest contributor to fisheries production in fulfilling fish consumption for the community.

Striped catfish is a commodity that is popular with the community because of its savory taste with affordable price. Striped catfish is widely cultivated by the community because it has several advantages, which are, striped catfish is easy to adapt in the aquatic environment, it can be cultivated on marginal land, it has a high endurance, and it also has a broad domestic market. Now there are many restaurants that provide menus with basic ingredients of striped catfish fillets that known as dory.

Basarang Village is a minapolitan location and the largest production location of striped catfish culture in the Kapuas Regency. The cultivation potential of striped catfish has a positive impact on people's income and employment opportunities. The amount of striped catfish production in Basarang Village is presented in Table 2. 
Tabel 2. Production of striped catfish in Basarang Village Kapuas Regency in 2011-2018

\begin{tabular}{|c|c|c|}
\hline No. & Year & Production (Ton) \\
\hline 1 & 2011 & 273,96 \\
\hline 2 & 2012 & 344,74 \\
\hline 3 & 2013 & 393,13 \\
\hline 4 & 2014 & 579,69 \\
\hline 5 & 2015 & 668,41 \\
\hline 6 & 2016 & 926,50 \\
\hline 7 & 2017 & 694,22 \\
\hline 8 & 2018 & 641.54 \\
\hline
\end{tabular}

Source : Official Report of the Fisheries and Maritime Division in Kapuas Regency in 2019

The high price of striped catfish is still the main attraction for producers and traders to sell this fish to the main markets in several regions in Kapuas Regency. The high price at the producer level will give a positive impact, it is because the profits obtained by producers will be even greater and will stimulate producers to increase the amount of production (Lilimantik, 2011). The price of striped catfish in Kapuas Regency from January to December 2018 is presented in Table 3.

Table 3. Price of the striped catfish in Kapuas Regency in 2018.

\begin{tabular}{|c|c|c|c|c|}
\hline \multirow{2}{*}{ No } & \multirow{2}{*}{ Month } & \multicolumn{3}{|c|}{ Price (IDR/kg) } \\
\cline { 2 - 4 } & & Producer & Middlemen & Retailer \\
\hline 1 & January & 18.000 & 20.000 & 25.000 \\
\hline 2 & February & 18.000 & 20.000 & 25.000 \\
\hline 3 & March & 18.500 & 20.500 & 26.500 \\
\hline 4 & April & 19.500 & 21.500 & 27.000 \\
\hline 5 & May & 20.000 & 22.000 & 26.500 \\
\hline 6 & June & 19.500 & 21.500 & 26.500 \\
\hline 7 & July & 19.500 & 21.500 & 28.500 \\
\hline 8 & August & 20.500 & 22.500 & 28.500 \\
\hline 9 & September & 21.000 & 23.000 & 27.500 \\
\hline 10 & October & 21.500 & 23.500 & 29.000 \\
\hline 11 & November & 20.500 & 22.500 & 24.000 \\
\hline 12 & December & 22.000 & 2000 & \\
\hline
\end{tabular}

Source : Official Report of the Fisheries and Maritime Division in Kapuas Regency in 2019

Anindita and Baladina (2017) explained that in an efficient market structure, the slightest change in price occurs in a market will cause price to fluctuate. Prices at the retail level will be the basis for determining the price to be paid to intermediary traders and ultimately to producers and vice versa. Furthermore, the price received by farmers will be a determinant of how much volume of production produced by producers to be sold to intermediary traders or retailers. If the price received is set, the production offered to the market will increase, and vice versa (Hanafiah and Saefuddin, 1996). Increased production is expected to meet consumer demand so that striped catfish can be distributed evenly in all regions.

\section{Literature Review}

Market reforms have been done in developing countries with the aim of improving market behavior, especially in the fisheries sector. This is because conducive market behavior can increase fair income for market participants, create jobs and food security. Successful market reforms can improve market efficiency and income distribution for market participants, including producers and consumers (Anindita and Baladina, 2017). Some indicators of market efficiency include improvement of distribution channels, and price improvements that can be seen from farmer's share, marketing margins and market structure, conduct and performance (Alma B, 2011).

Distribution is an activity that must be carried out to distribute, distribute, send and deliver the goods that have been market to consumers (Gitosudarmo I, 2014). Distribution is done so that goods that reach the consumer have a proper value and are right on target (Lilimantik E, 2019). Keegan, W.J., (2002) states that distribution channels are channels used by producers to distribute these goods from producers to consumers or industrial users. Distribution channels are institutions that market the products in the form of goods or services from producers to consumers. The main function of distribution channels is to distribute goods from producers to consumers, and in order to implementing and determining distribution channels the companies must take good consideration (Swasta B, 2008).

Distribution consists of two parts, namely (a) direct distribution, occurs when the producer himself/herself directly distributes the products to consumers as the last user without intermediaries and (b) indirect distribution, occurs if the goods that produced by producers are distributed to consumers through intermediary channeling 
institutions which is not part of producer organizations (Lilimantik E, 2007). The distribution channel will run well if there is no change in prices, because the amount of consumer demand is influenced by price changes (Lilimantik E, 2016). Price is a value expressed in rupiahs used for transactions or a sum of money that consumers must pay to obtain goods and services (Shinta, Agustina, 2011). Price is the only element of the marketing mix that provides income for the company (Rosson P., 1974). Changes in prices will affect the amount of public demand for fishery products (Masyrofie, 1994).

The amount of price received by marketing institutions is the difference between the price paid by consumers and the price received by producers, called the marketing margin (Kohl and Uhl, 2002). Marketing margins can also be interpreted as a sum of marketing costs and the amount of profit from each marketing institution involved (Sudiono A, 2004). The more institutions involved, the greater the marketing margins (Dahl and Hammond, 1977). According to Lantican (1999), high marketing margins can occur due to marketing costs that are too excessive. Thomson (1951) argues that a good marketing system is characterized by a smaller marketing margin value compared to the share of prices received by producers with the assumption for a perfect competitive market.

The size of the price received by the producer is the comparison of the selling price at the producer level with the purchase price at the consumer level, called the farmer's share (Dahl and Hammond, 1977). Usually this comparison is expressed as a percentage (Limbong and Sitorus, 1987). Farmer's share has a negative relationship with marketing margins because the higher the marketing margins, the lower the share that producers will get (Kinnucan and Forker, 1986). The value of the farmer's share aims to measure how much share is received by producers when marketing fisheries commodities (Sudiono, 2004).

The formation of the price of a commodity at a level of marketing institutions is also influenced by the structure, behavior and appearance of the market (Limbong and Sitorus, 1987). The SCP approach is used to monitor the competition between producers and marketing institutions in a market. There are three main elements in the market structure, namely market share, concentration (market concentration) and barriers to entry the market (Martin, 2002). According to Anindita and Baladina (2017), SCP is a criterion for knowing how far the marketing process goes and to know how well the marketing objectives are.

\section{Research Method}

\subsection{Research Approach}

The sampling method for striped catfish farmers uses the simple random sampling method, which is a sampling method where members of the population have the same opportunity to be selected as a sample (Sugiarto et al, 2003). Sampling for marketing institutions (collectors and retailers) uses the snowball sampling method, which is a method for identifying, selecting and taking samples in a network or chain of continuous relationships (Neuman, 2014). The samples in this study are 25 producers, 4 traders and 25 retailers.

The data used are primary data and secondary data. Primary data are obtain from survey results and interviews with respondents (Nazir, 2011). The data collection used is the interview, using an interview guide (Bungin, 2006). Interview guidelines usually contain detailed questions about what data or information researcher want to get from the interviewee by observe and pay attention to the development of the context and situation of the interview (Neuman, 2014). Bungin (2006) explained that secondary data was taken from literature studies and studies of data and information related to both the results of previous studies and other supporting data derived from several publications that already conduct.

\subsection{Analysis Method}

\subsubsection{Marketing Channel}

Marketing channel analysis is conducted to see each marketing channel that is passed from the producer level to the consumer level. The technique of determining the sample using snowball sampling. According to Sugiyono (2005), snowball sampling is a technique for determining a sample that is initially small in number, then this sample is told to choose its friends to be sampled and so on, so that the number of samples increases.

\subsubsection{Farmer's Share}

Farmer's share analysis is used to see a portion of the prices received by producers from retailers calculated using the formula (Kohls and Uhl, 2002) :

$$
\mathrm{Fs}=\underset{\mathrm{Pr}}{\mathrm{Pf}} \mathrm{\times 100 \%}
$$

Description :

$$
\begin{array}{ll}
\text { Fs } & =\text { Farmer's share } \\
\mathrm{Pf} & =\text { Price of farm } \\
\mathrm{Pr} & =\text { Price of retail }
\end{array}
$$


Dahl and Hammond (1977) explained the Farmer's share criteria, namely if the share of prices received by producers was higher than $50 \%$, then the marketing system is efficient.

\subsubsection{Marketing Margin}

Marketing margin analysis is used to see how much the price received by the trader. To find out the margin value, the following mathematical model is used (Tomek and Robinson, 1981) :

Description :

$$
\mathrm{MM}=\mathrm{Pr}-\mathrm{Pf}
$$

$\begin{array}{ll}\mathrm{MM} & =\text { Marketing margin } \\ \mathrm{Pf} & =\text { Price of farm }\end{array}$

$\operatorname{Pr} \quad=$ Price of retail

\subsubsection{Structure, conduct and performance}

\subsubsection{Market Integration Analysis}

Market integration can be sought by using regression analysis with the assumption that if the price of other factors is fixed, the price at the producer level and the price at the consumer level is linear. The equation model is as follows Azzaino (1982):

$$
\mathrm{Pf}=\alpha+\beta \operatorname{Pr}
$$

The regression coefficient between $\mathrm{Pr}$ and $\mathrm{Pf}$ is:

Description :

$$
\boldsymbol{\beta}=\frac{\sum \mathbf{P r} . \mathbf{P f}-\left(\sum \mathbf{P r} \cdot \sum \mathbf{P f}\right) / \mathbf{n}}{\left(\sum \mathbf{P r}^{2}-\left(\sum \mathbf{P r}\right)^{2} / \mathbf{n}\right)\left(\sum \mathbf{P f}^{2}-\left(\sum \mathbf{P f}\right)^{2} / \mathbf{n}\right)}
$$

$\begin{array}{ll}\operatorname{Pr} & =\text { Price of retail } \\ \mathrm{Pf} & =\text { Price of farm } \\ \mathrm{n} & =\text { Number of samples } \\ \alpha & =\text { Interception } \\ \beta & =\text { Regression coefficient }\end{array}$

Criteria for analysis of market integration (Azzaino, 1982):

1) If the value of $\beta>1$, then the market structure is monopoly or oligopoly.

2) If the value of $\beta<1$, the market structure is monopsony or oligopsony and

3) If $\beta=1$, the market is perfectly integrated.

\subsubsection{Analysis of Price Transmission Elasticity}

The price transmission elasticity is used to determine the relationship between prices at producer level and prices at consumer level. The price transmission elasticity is formulated as follows (George and King, 1971):

$$
\eta=\boldsymbol{\beta}_{\operatorname{Pf}}^{\operatorname{Pr}}
$$

Price Transmission Elasticity Criteria (George and King, 1971):

1) If $\eta=1$, it means that a $1 \%$ price change at the consumer level results in a $1 \%$ change at the producer level so that price changes are elastic.

2) If $\eta<1$, it means that a $1 \%$ price change at the consumer level will result in a price change of less than $1 \%$ at the producer level so that the price change is in elastic.

3) If $\eta>1$, it means that a $1 \%$ price change at the consumer level results in a price change of more than $1 \%$ at the producer level so that the price change is in elastic.

\section{Result And Discussion}

\subsection{Marketing Channel}

The pattern of striped catfish marketing channel in Basarang Village, Basarang Sub-District, Kapuas Regency, Central Kalimantan, consists of two channels that can be seen in Figure 1.

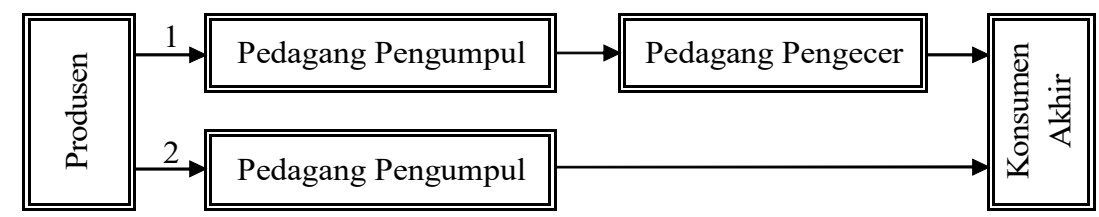

Figure 1. Marketing channel of striped catfish in Basarang Village, Basarang Sub-District, Kapuas Regency, Central Kalimantan.

Figure 1 explains that there are 2 marketing channels of striped catfish in Basarang Village, but the most is pattern 1, becauses: 
a. Producers are more interested in conducting transactions directly with the middlemen because it is not effective to sell directly to retailers, because they considered the transportation costs and risks that will be borne.

b. Most middlemen are in the production area so they can directly buy fish and sell it to retailers. The middlemen is a regular subscription for producers so that every time the harvest is produced, producers do not need to market their products to other places.

c. The middlemen already have a close relation with retailers.

d. Consumers buy more striped catfish at retailers, because retailers are located at the consumption location.

\subsection{Farmer's Share}

Table 4. Farmer's share of the striped catfish marketing produced by ponds in Basarang Village, Basarang SubDistrict, Kapuas Regency, Central Kalimantan.

\begin{tabular}{|c|c|c|c|}
\hline Marketing Channel & Price of farm (IDR/kg) & Price of retail (IDR/kg) & Farmer's share (\%) \\
\hline 1 & 18.180 & 25.640 & 70,90 \\
\hline 2 & 18.180 & 21.000 & 86,57 \\
\hline
\end{tabular}

Source : Processed primary data (2019)

Table 4 explains that the share price received by producers in channel 1 is $70.09 \%$ and in channel 2 is $86.57 \%$ of the price paid by consumers. Farmer's share value that greater than $50 \%$ indicates that the marketing system is efficient.

\subsection{Marketing Margin}

Table 5. The marketing margin of striped catfish pond cultivation in Basarang Village Basarang Sub-District, Kapuas Regency, Central Kalimantan.

\begin{tabular}{|c|c|c|c|}
\hline Marketing Channel & Price of farm (IDR/kg) & Price of retail (IDR/kg) & Margin (\%) \\
\hline 1 & 18.180 & 25.640 & 7.460 \\
\hline 2 & 18.180 & 21.000 & 2.820 \\
\hline
\end{tabular}

Source : Processed primary data (2019)

Table 5 explains that the marketing margin of the first channel pattern IDR 7.460, is higher than the second channel pattern IDR 2.820. This is because the first channel pattern is longer due to the large number of marketing institutions involved and each marketing institution involved will certainly take profit.

\subsection{Structure, Conduct and Performance}

\subsubsection{Market Integration Analysis}

In this research the marketing institutions involved consist of producers, middlemen and retailers, so from the market level perspective, it is included in vertical integration with the aim of seeing the integration of prices between producer markets and consumer markets.

Table 6. Results of price regressions at the producer level and prices at the retail level

\begin{tabular}{|c|c|c|}
\hline No. & Coefficient & Value \\
\hline 1. & $\alpha$ & 1.606 \\
\hline 2. & $\beta$ & 0,083 \\
\hline
\end{tabular}

Table 5 explains that the results of the regression analysis of fish prices at the producer level with prices at the retailer's level shows regression coefficient values is not equal to one $(\beta<1)$, meaning that an increase in price of IDR 1, - at the retail level followed by a price increase of IDR 0.083 at the producer level. This shows that the market structure formed is monopsony or oligopsony because the market is not perfectly integrated, which is caused by: (1) the distance between the two markets is relatively far so that transportation costs are high, (2) the market structure that deviates from perfect competition that is the practice oligopsoni. It is corresponding to the process that occurred in Basarang Village, Basarang Sub-District, where striped catfish farmers have a close relation with some of the traders where they sell their products.

\subsection{Analysis of Price Transmission Elasticity}

Analysis of price transmission elasticity is done to see the sensitivity of price changes at the producer level as a result of price changes at the consumer level.

Table 7. The ratio prices of farm to prices of retail and the value of price transmission elasticity $(\eta)$

\begin{tabular}{|c|c|c|c|}
\hline \multirow{2}{*}{ No. } & \multirow{2}{*}{ Symbol } & Channel 1 & Channel 2 \\
\cline { 3 - 4 } & & 0.709 & 0.866 \\
\hline 1. & $\operatorname{Pr} / \mathrm{Pf}$ & 0.059 & 0.072 \\
\hline 2. & $\eta$ & Dalue & \\
\hline
\end{tabular}

Table 6 explains that the value of the transmission elasticity of the two channel patterns in the striped catfish market is less than $1(\eta<1)$, namely for pattern 1 which is 0.059 and pattern 2 which is 0.072 . This means 
that if there is a $1 \%$ price change at the consumer level, it will cause a price change of $0.059 \%$ at the producer level in channel 1 and a price change of $0.072 \%$ at the producer level at channel 2 , so the price transmission elasticity is in elastic. The small value of the price elasticity is due to the marketing of production results, producers are dependent on collector so that they become determinants of prices in each transaction.

\section{Conclusion}

1. Striped catfish marketing channel in Basarang Village, Basarang District, Kapuas Regency, Central Kalimantan Province consists of two channels :

a. Producer $\rightarrow$ Middlemen $\rightarrow$ Retailer $\rightarrow$ Consumer

b. Producer $\rightarrow$ Middlemen $\rightarrow$ Consumer

2. Farmer's share in channel 1 is $70.09 \%$ and in channel 2 is $86.57 \%$ of the price paid by consumers. Farmer's share value greater than $50 \%$ indicates that the marketing system is efficient.

3. The marketing margin of the first channel pattern is IDR 7.460 which is higher than the second channel pattern that only IDR 2.820 .

4. The results regression analysis of prices of farm with prices of retailer shows regression coefficient values is not equal to one $(\beta<1)$, while the value of the transmission elasticity of the two channel patterns in the striped catfish market is less than $1(\eta<1)$, namely for pattern 1 which is 0.059 and pattern 2 which is 0.072 . This means that if there is a $1 \%$ price change at the consumer level, it will cause a price change of $0.059 \%$ at the producer level in channel 1 and a price change of $0.072 \%$ at the producer level at channel 2 , so the price transmission elasticity is in elastic.

\section{References}

Alma B, 2011. Marketing Management and Marketing Services. Alfabeta Publisher, Bandung.

Anindita dan Baladina, 2017. Marketing of Agricutural Products. PT. ANDI Publisher, Yogyakarta. 304 page.

Azzaino, 1982. Introduction to Agricultural Trading. Agriculture Department. Agricultural Social Economics Sciences. IPB, Bogor.

Bungin B., 2006. Quantitaive Research Data Analysis. Jakarta : Raja Grafindo.

Dahl dan Hammond, 1977. Market and Price Analysis, The Agricultural Industries. Mc Graw Hill Book Company, New York.

George dan King, 1971. Consumer Demand for Food Comodities in the United States With Project for 1980. Gianini Foundation Monograph.

Gitosudarmo I, 2014. Marketing Management. BPFE Publisher, Yogyakarta.

Hanafiah dan Saefuddin, 1996. Fisheries Product Administration. UI Press Publisher, Jakarta.

Kinnucan, H.W dan Forker, 1986. Asymmetry in Farm-Retail Price Transmission for Major Dairy Product. American Journal Agricultural Economics Vol. 74.

Kohls, R. L. and J. N. Uhl. 2002. Marketing of Agricultural Products. A Prentice-Hall Upper Saddle River, New Jersey.

Lantican, F.A., 1999. The Agribusiness Marketing System. Unpublished paper, Collage of Economic and Management, University of the Philippines Los Banos.

Lilimantik, 2007. Marketing of Fishery Products. Unlam Press Publisher, Kalimantan Selatan.

Lilimantik, 2011. Structure, Conduct and Performance Market of Goldfish Cultivation (Cyprinus carpio) in Karamba, Banjar Regency, South Kalimantan. Journal of the Development of Sustainable Nature Vol. 1 No. 2.

Lilimantik, 2016. The Marketing of Fresh Sea Fish in Tanah Laut Regency, South Kalimantan. Proceedings of the National Seminar on Agribusiness and Rural Economic Development III. Trunojoyo University. Madura, East Java.

Lilimantik, 2019. Supply Chain Management in the Catfish Seed Market. International Journal of Supply Chain Management (IJSCM) Volume 8, Number 4. Excelling Tech.

Limbong, W. H. dan Sitorus, P. 1987. Introduction to Agricultural Commerce, Departement of Agriculture Social Economic Sciences, Faculty of Agriculture IPB. Bogor.

Nazir, 2011. Research Method. $6^{\text {th }}$ edition. Ghalia Indonesia Publisher. Bogor

Neuman, W.L., 2003. Qualitative and Quantitative Approach. Social Research Methods. Boston : Allyn and Bacon.

Keegan, W.J., 2002. Global Marketing Management. Pearson Education, Delhi. P.194.

Martin, Stephen. 2002, Advanced. Indusrtrial Economic. Blackwell. Publishing. United Kingdom.

Masyrofie, 1994. Agricultural Product Marketing. Faculty of Agriculture Universitas Brawijaya, Malang.

Official Division of Kapuas Fisheries and Marine, 2019. Annual Report Official Division of Kapuas Fisheries and Marine.

Rosson P. ,1974. “Changing Traditional Distribution Systems : Fish Marketing In Tanzania”, Journal of Physical 
Distribution, No. 4, Vol. 5.

Shinta, Agustina. 2011. Marketing Management. UB Press. Malang.

Sudiono, A., 2004. Agricultural Marketing. Universitas Muhammadiyah Malang Press.

Sugiarto et al, 2003. Sampling Technique. Gramedia Pustaka Utama. Jakarta.

Sugiyono. 2005. Administrative Research Method. Alfabeta Publisher, Bandung.

Swasta B., 2008. Marketing Principles. Libery Press. Yogyakarta. 352 pages.

Thomson, 1951. Agricultural Marketing. New York, Toronto and London.

Tomek W. G dan Robinson K. L , 1981. Agricultural Product Price. Cornell University Press. London. 